\title{
$\mathrm{Az}$ újabb orális tumorellenes készítmények mellékhatásprofiljának, interakcióinak és az adherencia problémáinak áttekintése
}

\author{
Bartal Alexandra dr. ${ }^{1}$ - Mátrai Zoltán dr. ${ }^{2}$ - Szúcs Attila dr. ${ }^{1}$ \\ Belinszkaja Galina dr. ${ }^{3}$ - Langmár Zoltán dr. ${ }^{5}$ - Rosta András dr. ${ }^{4}$ \\ Országos Onkológiai Intézet, ${ }^{1}$ Intézeti Gyógyszertár, ${ }^{2}$ Általános és Mellkassebészeti Osztály, \\ ${ }^{3}$ Aneszteziológiai és Intenzívterápiás Osztály, ${ }^{4}$ "A” Belgyógyászati-Onkológiai és Hematológiai Osztály, Budapest \\ ${ }^{5}$ Semmelweis Egyetem, Általános Orvostudományi Kar, II. Szülészeti és Nőgyógyászati Klinika, Budapest
}

\begin{abstract}
Az orálisan alkalmazott daganatellenes gyógyszerek elterjedése az onkológiai ellátás minden területére hatással van, és fontos kérdéseket vet fel a biztonságos gyógyszerfelhasználás és az adherencia (a beteg alkalmazkodásának mértéke a gyógyszer szedésével kapcsolatos orvosi előírásokhoz) témakörökben is. Az elmúlt 10 évben számos új célzott terápiás készítmény került forgalomba, paradigmaváltást idézve elő a gyógyszeres onkológiában. A kezelóorvossal részletesen egyeztett terápia pontos követése, az adherencia fokozása, valamint a mellékhatások időbeli észlelése és adekvát ellátása céljából a rendszeres orvos-beteg találkozás és a megfelelő betegoktatás alapvető. Mivel viszonylag kevés ismeret áll rendelkezésre magyar nyelven az új gyógyszerekról, a szerző́k szándéka volt, hogy áttekintést adjanak az ezekkel kapcsolatos alapvetô tudnivalókról, betegbiztonsági kérdésekról, mellékhatásokról és interakciókról. $\mathrm{Az}$ áttekintés alapjául a hazánkban is forgalmazott, felnőttek kezelésében alkalmazott, orális bevételre formulált daganatellenes készítmények alkalmazási előiratai és a szakirodalomban publikált farmakokinetikai, interakciós, valamint mellékhatásprofilt felmérő vizsgálatok adatai szolgáltak. Orv. Hetil., 2012, 153, 66-78.
\end{abstract}

Kulcsszavak: daganatellenes kezelés, orális gyógyszerbevitel, interakciók, mellékhatások, adherencia

\section{Novel oral anticancer drugs: a review of adverse drug reactions, interactions and patient adherence}

Each aspect of oncological care is widely affected by the spread of oral anticancer agents, which raises several questions in terms of safe medication use and patient adherence. Over the past decade targeted therapies have appeared in clinical practice and revolutionized the pharmacological treatment of malignancies. Regular patient - doctor visits and proper patient education is crucial in order to comply with the therapy previously agreed upon with the oncologist, to increase patient adherence, to detect and to treat adverse effects in early stages. Since the information on the new medicines in Hungarian language is sparse it is the intention of the authors to give an overview of the basic knowledge, patient safety issues, adverse effects and interactions. Official drug information summaries and data on pharmacokinetics, interactions and adverse effects from the literature are reviewed as the basis for this overview. Orv. Hetil., 2012, 153, 66-78.

Keywords: anticancer treatment, peroral, oral administration, interactions, adverse effects, adherence

(Beérkezett: 2011. október 9.; elfogadva: 2011. november 9.) 


\section{Rövidítések}

AUC = (area under the curve) görbe alatti terület; CAM = (complementary and alternative medicine) komplementer és alternatív medicina; $\mathrm{C}_{\max }=$ maximális plazmakoncentráció; DDI = (drug-drug interaction) gyógyszer-gyógyszer kölcsönhatás; EGFR = epidermális növekedési faktor receptor; EMEA = (European Medicines Agency $)$ Európai Gyógyszerügynökség; FDA = (Food and Drug Administration $)$ Egyesült Államok Gyógyszerügynöksége; HDAC = hiszton-deacetiláz; HER2 = 2-es típusú humán epidermális növekedési faktor receptor; HFSR = (hand-foot skin reaction) kéz-láb bőrreakció; MEMS = microelectronic monitoring system; $\mathrm{mTOR}=$ mammalian target of rapamycin; NPSA $=$ National Patient Safety Agency (Egyesült Királyság); P-gp = P-glikoprotein; $\mathrm{RCC}=($ renal cell carcinoma $)$ vesesejtes rák; TKI $=$ tirozinkináz-inhibitor

Bár már évtizedek óta ismertek a szájon át alkalmazható daganatellenes kemoterápiás szerek, az elmúlt 10 évben új generációs, célzott készítmények kerültek forgalomba, paradigmaváltást idézve elő a gyógyszeres onkológiában [1]. Mérföldkövet jelentett a capecitabin engedélyezése a Food and Drug Administration (FDA) által 1998-ban, amit 2001-ben az imatinib, 2003-ban a gefitinib, 2004-ben pedig az erlotinib követett. A $\mathrm{Na}$ tional Comprehensive Cancer Network egyik 2008-as beszámolója szerint az akkor fejlesztés alatt álló tumorellenes készítmények legalább egynegyedét orális bevitelre formulálták [2]. Mivel napjainkban a daganatos megbetegedéseket az orvostudomány már a kezelhetó krónikus kórképek közé sorolja, kezelésükben akár élethosszig tartó terápia is szükségessé válhat. A modern készímények döntően „citosztatikus” (nem „citotoxikus") jellegúek, és alkalmasak a hosszú távú, rendszeres napi alkalmazás, vagyis a folyamatos gyógyszer-expozíció megvalósítására. A molekuláris szintű monitorozási módszerek, az úgynevezett biomarkerek teszik lehetővé a tartós kezelés hatékonyságát fémjelző tumorregresszió vagy -progresszió folyamatos nyomon követését, illetve a kiújult daganat korai észlelését [2]. Az új orális gyógyszerek megjelenésével - eltérően a hagyományos kemoterápiás szerek kórházi ellátást igénylő intravénás alkalmazásától - radikálisan átalakult a daganatos betegek egy részének napi ellátása. Lényeges felismerés, hogy a betegre átruházott, saját terápiája feletti felelősségteljes irányítás csak megfelelő felvilágosítás és az orvos, illetve a beteg közös akarata és összhangja esetén lehet sikeres. Az ellátás rendszerszintû́ változásában a betegek megfelelő oktatásához, konzultációjához, illetve a szájon át alkalmazható terápiákat övező számos tévhit eloszlatásához jól képzett szakemberekre és kellően hosszú időre van szükség [3].

A 2000 óta az Európai Gyógyszerügynökség (European Medicines Agency - EMEA) által engedélyezett, szájon át adható, célzott daganatellenes gyógyszereket és indikációikat röviden az 1. táblázatban foglaltuk össze [4]. Az évtized első felében, a 2000-2005 vége közé eső időszak alatt három készítmény kapott forgalomba hozatali engedélyt, míg 2006 eleje óta napjainkig több mint 10 új gyógyszer jelent meg a gyógyszerpiacon, amelyek közül azonban néhánynak az engedélyét azóta vissza is vonták. Az alábbiakban tárgyalt daganatellenes szereket az utóbbi öt évben engedélyezték, hatásmechanizmusukat tekintve többnyire receptor tirozinkináz-

1. táblázat $\mid$ Az Európai Gyógyszerügynökség (EMEA) által 2000 óta engedélyezett és jelenleg is engedéllyel rendelkező, szájon át adható, célzott daganatellenes gyógyszerek és javallataik [4]

\begin{tabular}{|c|c|c|}
\hline Gyógyszer neve & $\begin{array}{l}\text { EMEA- } \\
\text { engedély } \\
\text { évszáma }\end{array}$ & Javallat \\
\hline Capecitabin & 2001 & Dukes III vastagbéldaganat, mCRC, gyomorrák, emlőrák \\
\hline Imatinib & 2001 & $(\mathrm{Ph}+) \mathrm{CML},(\mathrm{Ph}+) \mathrm{ALL},(\mathrm{Kit}+) \mathrm{GIST}$ \\
\hline Erlotinib & 2005 & NSCLC, hasnyálmirigyrák \\
\hline Sorafenib & 2006 & Terápiarezisztens HCC, RCC \\
\hline Sunitinib & 2006 & GIST, mRCC, pancreas neuroendokrin tumora \\
\hline Dasatinib & 2006 & Terápiarezisztens CML és $(\mathrm{Ph}+)$ ALL \\
\hline Nilotinib & 2007 & $(\mathrm{Ph}+) \mathrm{CML}$ \\
\hline Lapatinib & 2008 & HER2-pozitív mBC (capecitabinnal kombinációban, illetve aromatázinhibitorral) \\
\hline Gefitinib & 2009 & Helyileg előrehaladott vagy áttétes NSCLC, ahol kimutatható EGFR tirozinkináz-mutáció \\
\hline Everolimus & 2009 & Terápia (VGEF-targetált) -rezisztens, előrehaladott RCC \\
\hline Pazopanib & 2010 & Terápiarezisztens, előrehaladott RCC \\
\hline S-1 (tegafur/glimeracil/oteracil) & 2011 & Elörehaladott gyomorrák, cisplatinnal kombinációban \\
\hline
\end{tabular}

HCC = hepatocellularis carcinoma; RCC = (renal cell carcinoma) vesesejtes carcinoma; CTCL = (cutaneous T-cell lymphoma) cutan T-sejtes lymphoma; $\mathrm{mCRC}=$ áttétes colorectalis carcinoma; $\mathrm{CLL}=($ chronic lymphoid leukaemia $)$ krónikus lymphoid leukaemia; $\mathrm{CML}=(\mathrm{chronic}$ myeloid leukaemia) krónikus myeloid leukaemia; ALL = (acute lymphoid leukaemia) akut lymphoid leukaemia; NSCLC = (non-small cell lung cancer) nem kissejtes tüdőrák 
inhibitorok, és viszonylag kevés tapasztalat, bizonyítékon alapuló ajánlás áll rendelkezésre a velük kapcsolatos interakciókról és mellékhatásaikról.

A daganatellenes gyógyszerek fogalomkörébe direkt tumorellenes szerek (például capecitabin, fludarabin) és biológiai terápiás szerek (például erlotinib, imatinib, sunitinib) tartoznak, míg a hormon- (vagy antihormon-) terápia nem képezi ennek részét. Közleményünkben áttekintést kívántunk adni a forgalomban csak nemrég megjelent gyógyszerekkel kapcsolatos alapvető tudnivalókról, betegbiztonsági kérdésekről, mellékhatásokról és interakciókról. Az áttekintés alapjául a hazánkban is hozzáférhető, felnőtteknél alkalmazott, orális bevételre formulált daganatellenes készítmények alkalmazási előiratai és a szakirodalomban (PubMed, Medline) publikált farmakokinetikai, interakciós és mellékhatásprofilt felmérő vizsgálatok adatai szolgáltak.

\section{Újabb, szájon át szedhető, célzott daganatellenes gyógyszerek}

A jelátviteli utak blokkolásában és befolyásolásában elért fejlődés célzott terápiás gyógyszerek kifejlesztését tette lehetővé. A jelátviteli útvonalak specifikussága miatt a gátlás a sejten belül meghatározott locusban következik be, ami jellemző mellékhatásokkal állhat összefüggésben [1]. Az EMEA által az elmúlt öt évben engedélyezett, szájon át szedhető daganatellenes készítmények többnyire ilyen célzott hatású, új generációs, kis molekulatömegú gyógyszerkészítmények.

Ígéretesek az utóbbi évtizedben elterjedt, a daganat növekedésében, az érújdonképződésben és az áttétek progressziójában szerepet játszó receptor tirozin (és szerin/treonin) -kinázokat célzó, orális biohasznosulást mutató készítmények, amelyek már nemcsak a kemoterápiára refrakter vagy intoleráns esetekben használhatóak. A szomatikus mutációk vagy a kromoszómaállományban indukált változások következtében létrejövő proteinkináz-aktiváció a daganatképződés egyik jól ismert módja. A vesesejtes rák (renal cell carcinoma, RCC) és hepatocellularis carcinoma (HCC) kezelésére alkalmazható szorafenib a tumorsejtekben többek között a CRAF, BRAF, c-kit és Fms-szerű tirozinkináz-3 (FLT-3) protoonkogének aktivitását, valamint a daganat érellátásában fontos szerepet játszó vascularis endothelialis és thrombocytaeredetű növekedésifaktor-receptorokat (VEGFR-2, VEGFR-3 és PDGFR- $\beta$ ) gátolja [5]. A sunitinib a PDGFR- $\alpha$, PDGFR- $\beta$ és VEGFRl, VEGFR2, VEGFR3, a c-kit receptor, az FLT-3, a kolóniastimuláló faktor receptor és a gliasejtvonalból származó neurotróp faktor receptor gátlószere. Vesesejtes rák, imatinibbel szemben rezisztens gastrointestinalis stromalis carcinoma és neuroendokrin pancreastumorok kezelésében alkalmazzák [6].

Előrehaladott vagy áttétes, nem kissejtes tüdőrákban alkalmazzák a gefitinibet, az EGFR tirozinkináz-aktiváló mutációjának jelenlétekor [7]. A mutáció kimuta- tása az úgynevezett "high-resolution melting analysis” módszerrel elengedhetetlen a terápia elkezdéséhez, hiszen „target” hiányában értelmetlen a gefitinibkezelés. A lapatinib az epidermális növekedési faktor receptor 1 (EGFR, ErbBl) és humán epidermális növekedési faktor receptor 2 (HER2, ErbB2) intracelluláris tirozinkináz doménjeinek gátlója. Kombinációban (capecitabinnal vagy aromatáz inhibitorral) HER2-overexpresszáló emlőtumorok kezelésére javasolt [8]. Megjelentek a klinikai gyakorlatban a második generációs, többcélpontú tirozinkináz-inhibitorok is: a dasatinib, nilotinib, valamint pazopanib. A dasatinib és a nilotinib „új generációs” BCR-ABL kináz gátlók, amelyeket hatékonyan alkalmaznak az úgynevezett Philadelphia kromoszómapozitív krónikus myeolid leukaemiában (CML), annak imatinibkezelésre rezisztens eseteiben is $[9,10]$. A pazopanib a vascularis endothelialis növekedési faktor receptor-1 (VEGFR-1), VEGFR-2, VEGFR-3, PDGFR$\mathrm{a} / \beta$ és c-kit receptor tirozinkinázok hatékony gátlója. Vesesejtes carcinoma kezelésére engedélyezték használatát, de a csoport többi tagjához hasonlóan más tumortípusokban (nem kissejtes tüdőrák, ovarium- és lágyrészsarcomák) is vizsgálják hatékonyságát [11].

Az everolimus az mTOR (mammalian target of rapamycin) gátlószere. Az mTOR biokémiailag egy szerin/ treonin kináz, ami részt vesz a sejt proliferációjának, motilitásának, túlélésének és fehérjeszintézisének inzulinszerü növekedési faktorokon (IGF-1, IGF-2) keresztül történő szabályozásában, és egyben RCC esetén terápiás célpontja is [12].

Európában is készül teret nyerni a Japánban kifejlesztett és a szigetországban 1999 óta a gyomordaganatok kezelésében alkalmazott S-1 (TS-1, Taiho Pharmaceutical) nevet viselő kombinációs készítmény. Az S-1 „összetevói” a tegafur (az ismert citosztatikum, az 5-fluorouracil egyik prodrugja), a gimeracil (dihidropirimidin-dehidrogenáz inhibitor, amely az 5 -fluorouracil degradációját akadályozza meg) és az oteracil (orotátfoszforibozil-transzferáz inhibitor, amely csökkenti az 5-fluorouracil aktivitását az egészséges gastrointestinalis nyálkahártyában). Egyes terápiarezisztens betegségekben, illetve emlőrák esetében is alkalmazzák. Előnyeként az elörehaladott vagy kiújult gyomorrákos betegeknél az intravénás kezelésekhez képest elérhető jobb terápiás eredményeket és az alacsonyabb költségeket fogalmazták meg $[13,14]$.

Populációs farmakokinetikai adatok elemzése során nem találtak összefüggést a várható legalacsonyabb egyensúlyi plazmakoncentráció és a daganatos betegek neme, testsúlya, kora, etnikai származása és a kreatininclearance között, így a tirozinkináz-inhibitorokat fix dózisban adagolják, függetlenül a beteg testfelületétől. Desar és munkatársai azonban sunitinibbel kezelt elhízott betegnél (42 éves férfi, testtömegindex 44,3 $\mathrm{kg} / \mathrm{m}^{2}$ ) a gyógyszer plazmaszintjének rendszeres ellenőrzésekor jelentős csökkenést tapasztaltak a görbe alatti terület értékében (area under the curve, AUC) [15]. Megfigyeléseik szerint a szuboptimális plazmaszint ki- 
alakulása dózisemeléssel megelőzhető [15]. Hasonlóképpen, alacsony testtömegü betegeknél a relatív túladagolás miatt nagyobb mértékü lehet a toxicitás.

A fentebb említett gyógyszerek mellékhatásait, szokásos dózisait és citokróm P450 enzimrendszeren kialakuló interakcióit a 2. táblázatban foglaltuk össze [16].

\section{Betegbiztonság}

Az Angol Betegbiztonsági Ügynökséghez 2003 novembere és 2007 júliusa között három halálesetról és 400 egyéb jellegű súlyos, betegbiztonságot érintő incidensről érkezett panasz orális tumorellenes készítményekkel kapcsolatosan [17]. A panaszok felének hátterében roszszul megválasztott dózist, nem megfelelő gyakorisággal és nem kellő időtartamig folytatott gyógyszerszedést, valamint az egyszerre beszedett tabletták inadekvát mennyiségét állapítoták meg.

A bejelentések hatására az angol nemzeti egészségügyi szolgálat (National Health Services) rövid határidővel változtatásokat és kötelező érvényú irányelveket léptetett érvénybe $[17,18]$. Alapvető céljuk volt, hogy a szóban forgó gyógyszerek felírásában, adminisztrálásában, kiadásában részt vevő orvosok, nővérek, klinikai gyógyszerészek tevékenységüket ugyanolyan szigorú szabályok betartásával végezzék és ellenőrizzék, mint az intravénás kezelések esetében. Kötelezővé vált releváns kórházi protokollok létrehozása és széles körben való elérhetővé tétele. Meghatározták a felíró klinikai onkológus szakorvos által minden vényen kötelezően feltüntetendő adatokat (például magasság, testtömeg, számított testfelület), a gyógyszerész kötelességeit az ellenőrzés, kiadás, betegoktatás folyamatában, a nőverek teendőit, valamint a betegek széles körű tájékoztatásának (írásban és szóban) részleteit is [18]. Az orális tumorellenes gyógyszert elrendelő orvossal szemben elvárás, hogy felmérje a beteg alkalmasságát a terápiára, például képes-e lenyelni a tablettákat/kapszulákat, megérti-e az utasításokat, esetleg küzd-e memóriazavarral. Beleegyező nyilatkozat alárását követően, csak egy ciklusra elegendő gyógyszermennyiség kiadása javasolt, ami garantálja a kontrollvizsgálatokon való megjelenést is. Fontos kitétel, hogy a páciensek a gyógyszerrel kapcsolatos problémák és kérdések megoldásában kompetens szakemberrel bármikor kapcsolatba léphessenek [17].

A vezérfonal részét képezik az olyan esetek (például nyelési nehézség) megoldásai is, amikor a tablettákból vagy kapszulákból oldatot/szuszpenziót szükséges készíteni [17, 18].

\section{Mellékhatások}

A legújabb daganatellenes gyógyszerek magas specificitása nem jelenti egyben a mellékhatások mérséklődését a korábbi gyógyszerekhez képest. Mivel a jelen összefoglaló egy nem homogén gyógyszercsoporttal foglalkozik, a kapcsolódó mellékhatások széles skálán írhatók le
(2. táblázat) [16]. A daganatkezelésekkel kapcsolatos, a mindennapi önellátást is zavaró mértékú mellékhatások (például erős hasmenés, zavaró vagy fájdalmas bőrtünetek, neuropathia) miatt a beteg kezelőorvosa elől eltitkolva megtagadhatja a gyógyszer bevételét, ami a kezelés eredményességét veszélyeztetheti [19]. A kezelőorvossal részletesen egyeztetett terápia pontos követése, az adherencia növelése, a mellékhatások időbeli észlelése és adekvát ellátása céljából a rendszeres orvos-beteg találkozás és a megfelelő betegoktatás alapvető. Az alkalomnak egy külön időpontot érdemes szentelni; az oktatást végzőnek szülkséges felmérnie azokat a tényezőket, amik visszatarthatják a beteget a kezelésével kapcsolatos tudnivalók elsajátításában: memóriazavarok, korlátozott mozgás, negatív beállítottságú környezet, rossz szociális körülmények vagy idős kor $[3,20,21]$. Ideális esetben az ismertetés írásos, szóbeli és vizuális elemeket is tartalmaz, és a családtagokra, illetve a gondozókra is kiterjed. Az érintetteket „oktatási segédanyagokkal” is szükséges ellátni (betegeknek szóló gyógyszer-információ, gyógyszernapló, recept nélkül kapható készítményekkel kapcsolatos figyelmeztetés stb.). A tumorellenes gyógyszerekkel való kezelésekkel kapcsolatos mellékhatásokat és azok súlyosság szerinti beosztását az egyesült államokbeli National Cancer Institute által kidolgozott Common Toxicity Criteria for Adverse Events (CTC AE) tartalmazza [22]. A súlyossági fokozatok bevezetésével és alapos leírásával egy, a klinikumban és klinikai vizsgálatokban is jól alkalmazható rendszert hoztak létre.

Az alábbiakban néhány alapvető tudnivalót foglaltunk össze a leggyakoribb mellékhatásokról.

\section{Hányinger és hányás}

Az émelygés és a hányás a per os kezeléseknél is gyakori mellékhatás. Nem megfelelő csillapítása esetén a betegben félelmet generál a következő dózis bevételével szemben. Az antiemetikumok megfelelő alkalmazása ezért kiemelten fontos a nonadherencia megelőzésében. A szelektív szerotonin-3 receptorantagonisták (például ondansetron, granisetron) szájon át történő alkalmazása biztonságos, nem alakul ki kölcsönhatás köztük és a daganatellenes gyógyszerek között. Számos esetben a gastrointestinalis mellékhatások elkerülése céljából, kontraindikáció hiányában ajánlott a tablettákat étkezés közben bevenni vagy napi egyszer adagolni (3. táblázat) [20].

\section{Hasmenés}

Súlyosságát általában a napi székürítések számával mérik fel, és ha ez a szám tartósan 8-10 fölé emelkedik, dózismódosítás vagy a terápia felfüggesztése válhat szükségessé. Gyógyszeres megoldást jelenthet a loperamid vagy diphenoxylat alkalmazása. A loperamid (például $2 \mathrm{mg}$ hatóránként) akár hosszabb távon is alkalmas lehet a székürítések gyakoriságának csökkentésére, a széklet konzisztenciájának javítására és a hasmenés mértékének 
kontrollálására. Alkalmazása mellett is szükséges azonban a rendszeres folyadék- és ionpótlás azoknál a betegeknél, akiknél ez a mellékhatás megjelenik [20, 21]. $\mathrm{Az}$ étkezési tanácsadás fontos információkkal szolgálhat: sok folyadék fogyasztása, nem túl füszeres, pépes táplálék és az úgynevezett BRAT (banán, rizs, almaszósz és toast kenyér) diéta javasolható $[19,23]$. A kezeléssel járó egyéb gastrointestinalis panaszok, mint a puffadás, flatulentia, dyspepsia elkerülésében vagy enyhítésében is leginkább életmód- és táplálkozási változtatások segíthetnek: szénsavas italok és hüvelyes zöldségek kizárása az étrendből, illetve sajt, joghurt fogyasztása. Amennyiben hisztaminreceptor-antagonisták és protonpumpainhibitirok alkalmazása elkerülhetetlen, fontos, hogy bevételük legalább két órával térjen el a daganatellenes készítmény bevételének időpontjától.

\section{Magas vérnyomás}

Egyes tirozinkináz-gátlóknál (például sunitinib, sorafenib, pazopanib, vandetanib) és az abirateron alkalmazásánál jelentős problémát okozhat a gyógyszerek vérnyomást emelő hatása, ami a kezelés kezdetétől számított egy-két héten belül vagy lassan, hónapok alatt is kialakulhat. A pontos mechanizmus nem ismert, feltételezhető, hogy a presszorstimuláció, a gyarapodó extracelluláris térfogat és a véredények falának csökkenő rugalmassága hatására jelentkezik ez a mellékhatás $[24,25]$. A mikroerek csökkenő denzitása a vascularis ellenállás növekedését és a nitrogén-monoxid csökkent biohasznosulását okozhatja, ami végül magas vérnyomáshoz vezet. Kezdetben a vérnyomás rendszeres ellenőrzése szükséges, vagy orvos által, vagy otthon, önállóan. A tirozinkináz-gátlók okozta magas vérnyomás állandósulását a gyakorlatban sikeresen kezelik amlodipin és angiotenzin konvertáló enzim inhibitor kombinációjával, figyelembe véve, hogy a hypertoniában alkalmazott gyógyszerek egy része nem tûnt elég hatásosnak, és citokróm P450 enzimgátlók sem választhatók az interakciók elkerülése érdekében [25].

\section{Börfelszinen megjelenö mellékhatások}

A bőrt érintő mellékhatások meglehetősen gyakoriak a tirozinkináz-inhibitorok szedésével kapcsolatban. Kialakulásuk az epidermális vascularis növekedési faktor receptor gátlásával hozható összefüggésbe. Az „EGFRterápia” leggyakoribb, bőrt érintő mellékhatásai a papulopustularis kiütések az arcon és törzsön (60-81\%-os incidencia), körömelváltozások (12-16\%), xerosis (7-35\%), pruritus (10-16\%) és ritkán alopecia (5-6\%) [26]. Ezeket a mellékhatásokat leukopeniás betegeknél gyakran kísérheti bakteriális, virális és/vagy dermatophytid fertőzés [5, 26, 27, 28]. A bőrkiütések spontán eltünhetnek, a kezelés elhagyásával teljesen megszűnnek. A beteg arcát borító „rash” azonban pszichésen nagymértékben befolyásolhatja a terápia sikerességét, és a másodlagos fertőzések az életminőséget jelentősen ronthatják [5, 26, 28]. A kiütés megelőzésére és kezelésére - empirikusan - hidratáló bőrápoló, nappalra magas fokú UVA- és UVB-védelem, külsőleg clindamycingél és/vagy per os doxycyclin $2 \times 50 \mathrm{mg} /$ nap és helyi kortikoszteroid együttes alkalmazását javasolják $[26,27]$. Fontos megjegyezni, hogy egyes klinikai vizsgálatok megfigyelései szerint a „rash” megjelenése a terápia hatékonyságának jelzője, arra vonatkozólag viszont még nem született állásfoglalás, hogy a kiütés hiányának hátterében állhat-e terápiás hatástalanság [26].

A sorafenib és sunitinib kiváló biztonságossági profilja ellenére, egyes tanulmányok szerint, a betegek több mint 60\%-ánál jelentkezik a kéz-láb bőrreakciónak nevezett tünetegyüttes, ami az érintett területeken fájdalmas elváltozásokat és az epidermis hyperplasiáját okozza [8, 26, 28]. A gyógyszer szedésének megkezdése után kettő-négy héttel a tenyéren és talpon kialakuló mellékhatást a nagymértékű hasonlóság miatt sokáig az 5-fluorouracil és capecitabin által is kiváltott kéz-láb szindrómaként említette az irodalom [26, 28].

Súlyosabb, a mindennapi tevékenységeket és mozgást befolyásoló mellékhatások eseteiben dózismódosítás vagy akár a terápia felfüggesztése is szükségessé válhat [7, 26, 27, 28]. A napi dózis csökkentésével vagy elosztásával a mellékhatás sokszor jól kezelhető. A jelentkező kézszárazság miatt hidratálókrémek használata javasolt, illetve a bőr megvastagodásának, callus keletkezésének észlelésekor hámlasztó, szalicilát- vagy ureatartalmú készítmények alkalmazhatók. A hólyagok megjelenése, a bőr berepedezése esetén már a fentebb említett exfoliánsokkal való kezelés csak ronthat a helyzeten, ilyenkor regeneráló- és védőkrémek javasolhatók [28]. A dermatológiai mellékhatások észlelésekor bőrgyógyásszal történő mielőbbi konzultáció feltétlenül szükséges!

\section{Myeloszuppresszió}

$\mathrm{Az}$ orálisan alkalmazott készítmények is okozhatnak súlyos myeloszuppressziót, aminek következményeként neutropenia, thrombocytopenia alakul ki. Az akár súlyos mértéket elérő mellékhatás a testhőmérséklet rendszeres ellenőrzését és alapvető higiénés előírások betartását indokolják, de legfontosabb az, hogy a neutropenia első jeleinél (például gyengeség, láz) a beteg azonnal jelentkezzen onkológusánál, hogy az esetlegesen szükséges terápiát vagy a dózis módosítását időben meg lehessen kezdeni [29]. A thrombocytopenia és a következményes vérzékenység szintén kiemelendő, a vérkép rendszeres ellenőrzésével nyomon követhető, aminek nem feltétlen az onkológiai centrumban kell történnie, hanem a beteg otthonához közel, akár a háziorvosi rendelőben is végezhető [29]. Ennek megfelelően a családorvosok továbbképzése is fontos ezen a téren. Különösen veszélyeztetettek például az előzőleg sugárterápián átesett, sunitinibbel kezelt nasopharingealis daganatban szenvedő betegek, akiknél vérzésekre való fokozott hajlamot figyeltek meg [30]. 


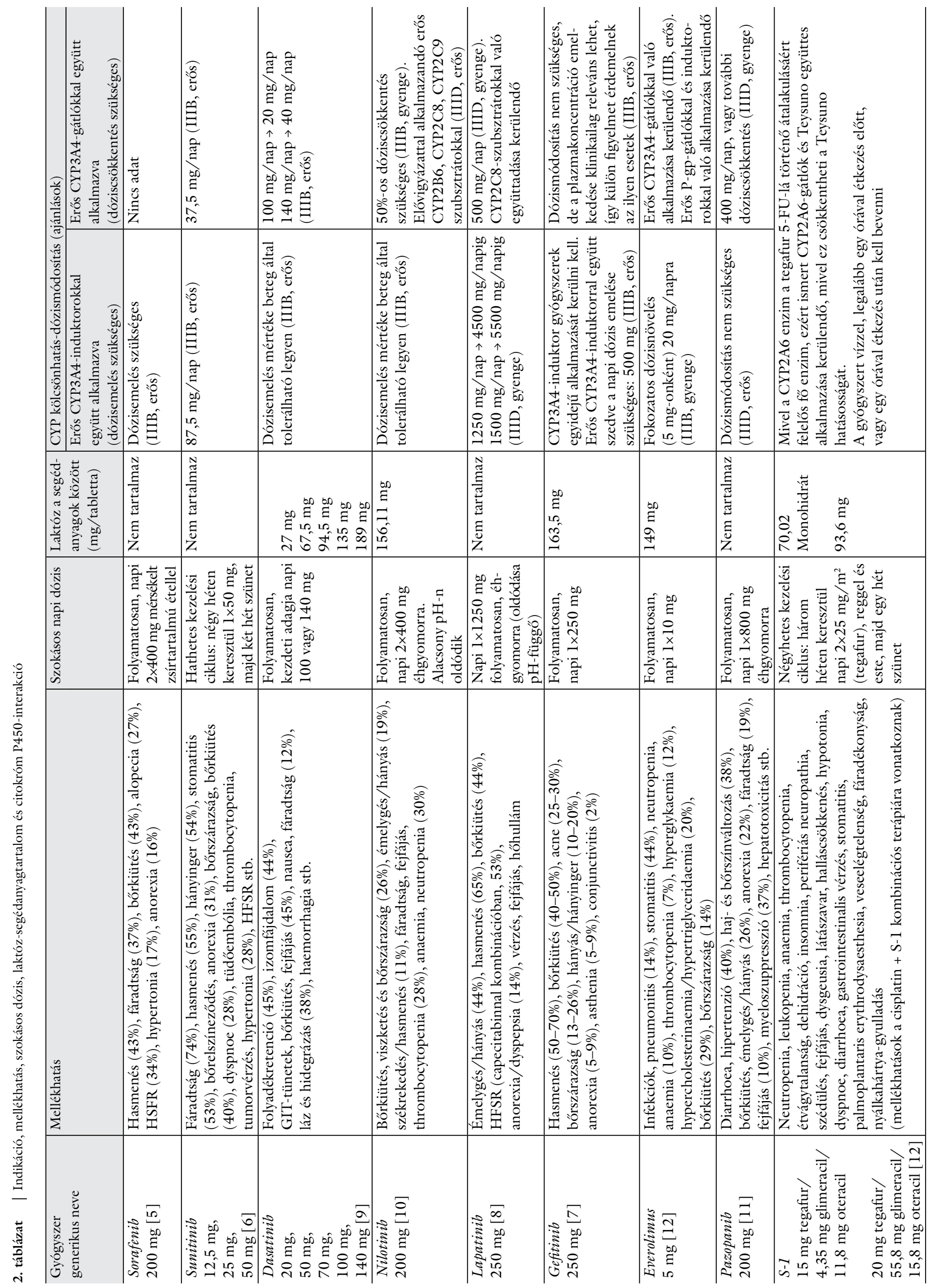




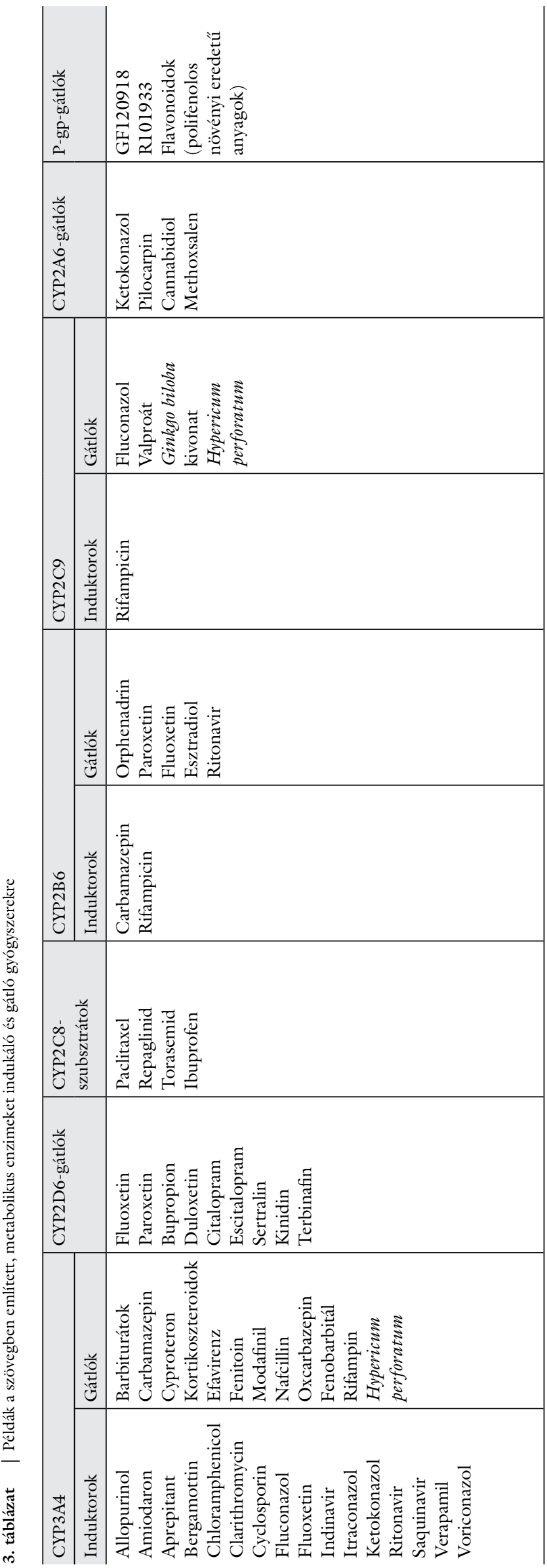

\section{Kimerültség, asthenia}

A daganatos betegségekkel járó fáradtság egy állandóan fennálló, kellemetlen, szubjektíven megélt fizikai, érzelmi és/vagy kognitív kimerültség, ami a daganattal vagy annak kezelésével függ össze. Mértéke nem arányos a beteg fizikai aktivitásával, és nagymértékben befolyásolja a mindennapi létet [31]. Az ilyen jellegú fáradtság leggyakrabban más tünetekkel - fájdalommal, zavartsággal, vérszegénységgel és alvászavarokkal - együtt jelentkezik. Fontos a beteg alapos kivizsgálása és szưrése több tünet vonatkozásában is, amelyek változó megjelenésűek és mértékűek lehetnek a diagnózistól, kezeléstôl és a betegség stádiumától függően. Mivel egy szubjektív „élményről” van szó, a kimerültség szisztematikus felmérése és értékelése szükséges, többek között a beteg saját elbeszélései alapján. A megfelelő kezelés a protokollok szerint történik. A napi rendszeres tevékenységek és a fizikai aktivitás felmérésével a betegnek tanácsolható a megterhelő mozgások csökkentése, több rövidebb részre osztása, egyes aktivitások csoportosítása, vagy más napszakba rendezése, a nappali alvások rövidítése és a figyelemelvonás (például zene, játék) alkalmazása. A nem gyógyszeres megoldások közé tartozik az állóképességet is fokozó kíméletes gyógytorna, masszázs, pszichoszociális terápia, étkezési tanácsadás, valamint a kognitív viselkedésterápia [31]. Amennyiben ezek a módszerek nem javítanak a beteg állapotán, és a kimerültség hátterében nem állapítható meg más ok, alkalmazható methylphenidat vagy modafinil, de a beteg folyamatos utánkövetése és állapotának a kimerültség szempontjából való felmérése a továbbiakban is szükséges [31].

\section{Hepatotoxicitás}

A tirozinkináz-inhibitorok súlyos májkárosodást okozhatnak. A hatásmechanizmus nem tisztázott, mint ahogy az sem, hogy a hepatotoxicitás az egész gyógyszercsoport jellemző mellékhatásának tekinthető-e. A súlyos májkárosodás definíciója akut májkárosodás (májfunkciós tesztek magas értéke, bilirubinaemia vagy sárgaság), ami társulhat a következók egyikével: halál, májtranszplantáció vagy a transzplantációs listára kerülés, hepaticus encephalopathia, alvadási zavar vagy vesekárosodás [32]. A hepatotoxicitás kialakulásának megelőzésére helyeződik a hangsúly, így fontosak a kezelés kezdetekor a megfelelő laboratóriumi vizsgálatok, valamint a terápia alatt történő folyamatos monitorozás, továbbá a rizikófaktorok felismerése. Ha májkárosodás alakul ki a kezelés során, a tumorellenes kezelés felfüggesztése válik szükségessé [32].

\section{Farmakokinetikai megfontolások}

A daganatos betegség stádiuma befolyásolja a farmakokinetikai paramétereket: az emésztőrendszerben kialakult funkciózavar az abszorpcióra, az albumin plazma- 
koncentrációjának csökkenése, a magas testzsírszázalék vagy folyadékgyülem keletkezése pedig a disztribúció karakterisztikájára van hatással [33]. Nagy variabilitást okozhat a gyógyszerek felszívódásában egyes esetekben a megelőző mưtét, sugárkezelés vagy kemoterápia, illetve a genetikai különbségek a gyógyszer-metabolizáló enzimek expressziójában.

Az ABCBl (ATP-binding cassette B l) gén által kódolt P-glikoprotein (P-gp) a daganatsejtek felszínén egy multidrugrezisztens pumpa, ami hatásosan távolít el xenobiotikumokat a tumorsejtek belsejéből, a vékonybél-epitheliumban is expresszálódik, és a gyógyszerek felszívódásának mértékét befolyásolja [34, 35, 36, 37]. A P-gp eltérései farmakokinetikai változásokban nyilvánulnak meg, ezért az ABCBl génpolimorfizmus miatti interindividuális $\mathrm{P}$-gp-különbségek tanulmányozása további vizsgálatok tárgya [38, 39, 40, 41, 42].

$\mathrm{Az}$ abszorpció után a gyógyszermolekulák plazmafehérjékhez (föleg albumin és $\alpha_{1}$ savas glikoprotein) nem kötődő hányada távozhat az intravascularis térből a gyógyszerhatás helyszínére. A rákos betegeknél nagy arányban előforduló alultápláltság és csökkent májmúködés (például áttétek miatt) gyakran vezet hypoalbuminaemiához. Az albuminhoz nagy affinitással kötődő gyógyszerek esetében ez megnövekedett szabad (i.e. albuminhoz nem kötődő) frakció kialakulásához vezet, a magasabb koncentráció pedig akár toxikus mellékhatások megjelenésében nyilvánulhat meg. Egyes gyulladásos állapotokban a magasabb $\alpha_{1}$ savas glikoprotein és más akutfázis-fehérjék szintjének emelkedése okoz nagyobb mértékü fehérjekötődést, így a „szabad” gyógyszer-koncentráció lecsökken, elméletileg a gyógyszerhatás elmaradását okozva [42]. Mindezek ellenére általános konszenzus alapján a plazmafehérjék mennyiségét változtató állapotokat a klinikai gyakorlatban nem tekintik befolyásoló tényezőnek a gyógyszerek döntő többségénél.

Érdekes megfigyeléseket tettek Baker és munkatársai, amikor egészségeseket hasonlítottak össze daganatos betegekkel a citokróm P450 enzimek aktivitásának szempontjából [43]. A daganatos betegek szervezetében az enzimek kisebb aktivitással voltak jelen, és ez a különbség nem magyarázható genetikai polimorfizmussal. Jelenleg pontosan nem lehet tudni, hogy mi áll a megfigyelés hátterében; egy elmélet szerint a citokinek emelkedett szintje, a máj nem megfelelő múködése és a fokozott gyulladásos reakciók [42, 43].

Végül, az exkréció folyamata is sérülhet daganatos betegekben, akár a vesét érintő malignus elváltozások, akár a korábbi kezelések során alkalmazott citosztatikumok által okozott szöveti károsodás következményeként. A célzott tumorellenes gyógyszerek általában kis molekulák vagy monoklonális antitestek [44]. Kis molekulasúlyú gyógyszerek leggyakrabban a vesén vagy a hepatobiliaris rendszeren keresztül ürülnek, míg a monoklonális antitestek metabolizmusának és exkréciójának több mozzanata máig ismeretlen [40]. Az itt tárgyalt daganat- ellenes szerek egységesek abban, hogy metabolizmusuk a májban történik, dominánsan a széklettel ürülnek, és kevésbé a vesén keresztül. Kivételt képez a nilotinib, ami csak széklettel távozik a szervezetból [10].

\section{Gyógyszerkölcsönhatások}

Két vagy több gyógyszer egyidejü alkalmazásakor gyakran felmerül az interakciók kérdése, akár vényköteles, akár recept nélkül kapható termékekkel, vagy komplementer, illetve alternatív medicina alkalmazásával (például gyógynövény-, illetve magas vitamintartalmú készítmények) párhuzamosan szedi a tumorellenes gyógyszert a beteg. A maladszorpció, malnutríció, a betegség bizonyos stádiumai és egyéni farmakokinetikai különbségek a kölcsönhatásokat esetenként előre jelezhetik [33]. Egyidejüleg alkalmazott gyógyszerek, vitaminok vagy élelmiszerek, amelyek a vizelet $\mathrm{pH}$-ját változtathatják, a renalis exkréciót is befolyásolhatják. A gyógyszergyógyszer interakciók megelőzhetők a korai felismeréssel, aminek hatékony módszere lehetne a beteg által szedett készítmények körültekintő felmérése, eszköze pedig olyan adatbázis, ami naprakész információkat tartalmaz az interakciókról a bizonyítékok értékelésével (evidenciaszintek) együtt [45].

A daganatos betegeknél leggyakrabban előforduló gyógyszer-interakciók hátterébben általában a citokróm P450 (CYP) enzimrendszer áll [46]. A metabolizmusban kiemelkedő szereppel bíró legfontosabb izoenzimek (CYP1A2, CYP2C19, CYP2C9, CYP2D6, CYP2E1 és CYP3A4) közül a CYP3A4 a legnagyobb figyelmet érdemlő ennek a betegcsoportnak a szempontjából [45, 46]. Wong és munkatársai 2008-ban két adatbázist (Drug Interaction Facts DIF és Micromedex DRUGDEX) elemeztek az orális tumorellenes és egyéb gyógyszerek közti, klinikailag releváns kölcsönhatások felmérésére. A legtöbb interakciót négy gyógyszercsoportnál találták: antikoagulánsok $(53,8 \%)$, hydantoinszármazékok $(42,8 \%)$, rifamycinek $(35,7 \%)$ és gombaellenes sze$\operatorname{rek}(32,1 \%)[45]$.

A legtöbb újabb orális daganatellenes szer esetében csak kevés adat áll rendelkezésre az interakciókat illetően. Az egyes itt tárgyalt gyógyszerek metabolizmusában szereplő és a 2. táblázatban említett izoenzimek aktivitásának fontosabb inhibitorait, induktorait, illetve egyes szubsztrátjait a 3. táblázat tartalmazza.

Nemcsak gyógyszerek léphetnek kölcsönhatásba a tumorellenes készítményekkel. A komplementer és alternatív medicina módszereinek alkalmazása az utóbbi 15 év során egyre növekvő tendenciát mutat, egészségügyi, gazdasági és társadalmi következményeket vonva maga után $[46,47]$. Európában különösen nagy figyelmet érdemel ez a jelenség, hiszen az irodalom döntő többsége az Egyesült Államokból származik, ahol egyes tanulmányok azt mutatták, hogy a daganatos betegek akár 73\%-ban alkalmazzák az alternatív terápia valamely faj- 
táját, leggyakrabban vitaminokat és ásványi anyagokat szednek változó, általában igen magas dózisban, gyógynövénytartalmú készítményekkel együtt [48]. A helyi viszonyok felmérése még várat magára. Egyre nagyobb érdeklődés övezi a készítmények daganatellenes terápiát befolyásoló lehetséges hatásait is. Mivel a legtöbb országban nem a gyógyszerek felügyeletéért felelős szervek ellenőrzik ezeket a többnyire gyógynövényalapú vagy „gyógyhatású” készítményeket, farmakológiai tulajdonságaikról és interakciós készségükről nem sok információ áll rendelkezésre. Az egészségügyi szakemberek gyakran aggodalmukat fejezik ki az alternatív készítmények sokszor pontosan nem is ismert összetevői és a magas árú daganatellenes szerek közt fellépő valós vagy vélt kölcsönhatások miatt.

A problémát jól szemléltető példa a közkedvelt nyugtató hatású teakeverékek fö összetevője, az orbáncfú (Hypericum perforatum). A gyógynövény olyan hatóanyagot tartalmaz, amely kötődik a pregnán X-receptorhoz (PXR), és ezáltal metabolikus enzimeket kódoló gének transzkripcióját befolyásolhatja $[49,50]$. Mivel ez a hatás a klinikai gyakorlatban is jelentős lehet, a legújabban FDA által törzskönyvezett tumorellenes gyógyszerek alkalmazási előiratában (például vandetanib) már egyértelmú figyelmeztetés olvasható a Hypericum perforatum kerülésére [50]. Mivel számtalan nemkívánatos interakció okozói a gyógynövénytartalmú készítmények, alkalmazásuk ma már rutinszerüen kizáró okot képez a klinikai vizsgálatok kapcsán [44]. További problémás és a daganatos betegek körében népszerû gyógynövények és vitaminok: echinacea (Echinacea angustifolia, E. pallida és E. purpurea), kava-kava, E- és A-vitamin, quercetin, ginseng, fokhagyma (Allium sativum), $\beta$-karotin, amelyekkel további vizsgálatok szükségesek a daganatellenes terápiákra gyakorolt hatásuk tisztázására [51].

Az idősek nagyobb veszélynek vannak kitéve, főleg, ha máj- vagy vesefunkciójuk károsodott, és más betegségben is szenvednek, illetve többféle gyógyszert szednek. A polifarmáciát, vagyis a több gyógyszerkészítmény rendszeres alkalmazását jellemzi, hogy ötféle gyógyszer esetében 50\%-ra becsülik az interakciók kialakulásának veszélyét, és 100\%-ra hétféle gyógyszer szedésekor [52, 53]. A mellékhatások 20-30\%-át is interakciók okozzák $[54,55]$.

A gyógyszerkölcsönhatások észlelése és elhárítása a daganatos betegeknél különösen nagy figyelmet érdemel, teljes körű feltérképezése még várat magára [55].

\section{Kezdeti dózismódosítások speciális esetekben}

A gyógyszer-expozíció mértéke függ a tumorellenes kezelés megindításakor fennálló máj- és vesefunkciós értékektől. Máj-, illetve veseelégtelenségben gyakran szükséges módosítani a szájon át adható daganatellenes készítmények dózisát.
Célzott készítményekre vonatkozólag részletes irodalmi áttekintést végzett egy szingapúri munkacsoport, akik nemcsak ezen szervi elégtelenségekre, hanem a dohányzással és a CYP-enzimrendszerrel kapcsolatos interakciókra és a dózismódosítás ajánlásaira is kitértek [55].

A dohányfüst policiklusos aromás hidrokarbon-vegyületeket tartalmaz, amelyek indukálják a CYPlAl, CYPlA2 és CYP2El enzimeket, így az általuk is metabolizált tumorellenes gyógyszerek (például erlotinib, imatinib) dózisának emelése lehet szükséges [56].

A máj központi szerepe vitathatatlan a gyógyszerek döntő többségének metabolizmusában és diszpozíciójában (plazmaprotein kötődésében és biliáris exkréciójában). Elégtelen múködése egyes esetekben a gyógyszer akkumulációjához vagy a toxikus mellékhatások fokozottabb megjelenéséhez vezet. Így megfogalmazódhat a bizonyítékokon alapuló, dózis módosítására vonatkozó ajánlások összeállításának igénye is [16]. Jelenleg nincs elég tudományos információ ahhoz, hogy hasonló ajánlásokat lehessen tenni lapatinib-, dasatinib- és everolimuskezelésekre vonatkozóan, de az ismert, hogy minimális ( $<5 \%)$ hányaduk ürül változatlan formában a vesén keresztül, így „renalis dózis” megállapítása gyakorlatilag szükségtelen [57, 58]. A nilotinib esetében mind a gyógyszermolekula, mind pedig metabolitjai széklettel ürülnek, ezért ilyenkor szükségtelen módosítani a dózist [10]. Az egyes készítmények kezdő adagjainak módosításaira vonatkozó ajánlásokat szervi elégtelenségben a 4. táblázat foglalja össze.

\section{Gyógyszer-étel interakciók}

Koch és munkatársai az elfogyasztott élelmiszer hatását vizsgálták a lapatinib biohasznosulására 27 előrehaladott állapotú, szolid daganatos betegnél. A vizsgálatban a betegek három hétig heti egyszer éhgyomorra és alacsony, illetve magas zsírtartalmú reggelivel is beszedték az 1500 mg dózist [59]. Eredményeik szerint, az alacsony zsírtartalmú reggeli hatására 2,67-szorosára (167\%) nőtt a lapatinib esetében az AUC, és 2,42-szorosára (142\%) a maximumkoncentráció $\left(\mathrm{C}_{\max }\right)$. A magas zsírtartalmú reggeli 4,25-szoros (325\%) növekedést okozott az AUCban és 3,03-szoros (203\%) növekedést a $\mathrm{C}_{\max }$-ban, az éhgyomorra bevett gyógyszer ugyanezen értékeivel öszszehasonlítva [59]. Az étkezésnél tapasztalt nagyobb biohasznosulás és a szisztémás gyógyszer-expozíció nagyobb abszolút variabilitása alátámasztja az éhgyomorra való gyógyszerbevétel ajánlását az egyenletes terápiás expozíció elérése céljából [59].

Ugyan a tárgyalt gyógyszerek egy részénél a farmakokinetikát az étel nem befolyásolja, fontos a betegek figyelmét felhívni arra, hogy a nem következetes étkezési és gyógyszerbeviteli szokások olyan veszélyeket hordoznak, mint a mellékhatások gyakoribb megjelenése vagy éppen a csökkent gyógyszerhatás, ami a kezelés egészére is hatással lehet. 


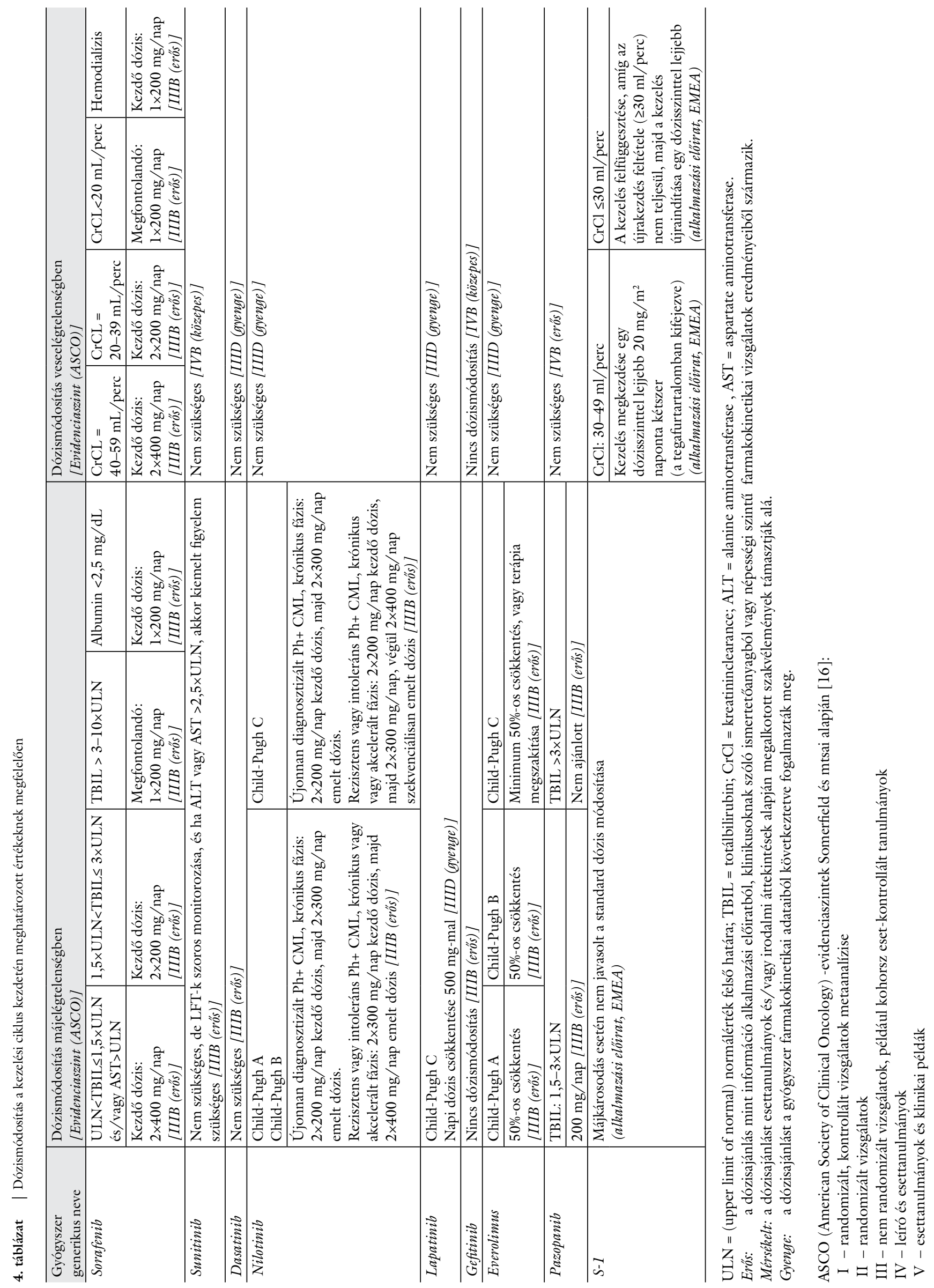




\section{Az adherencia kérdése}

A „compliance” fogalma annak mértékét fejezi ki, hogy a beteg viselkedése a gyógyszeres terápiában mennyire egyezik meg az orvosa által elóírtakkal [60]. A fogalmat sokan bírálták az orvos-beteg kapcsolat szempontjából esetlegesen negatív kicsengése miatt. Az adherencia kifejezés ennél többet takar, és annak mértékét kívánja kifejezni, amennyire a beteg viselkedése megegyezik a kezelőorvosa által javasolt, de a pácienssel egyetértésben kialakított terápiával. A legújabb kapcsolódó fogalom a „konkordancia”, amelyet leginkább az Egyesült Királyságban alkalmaznak, és magába foglalja a betegoktatástól kezdve a terápia teljes ideje alatt történő támogatást. $\mathrm{Az}$ angol szakmai panel az adherenciát ajánlja, mint a beteg gyógyszerszedését jellemző kifejezést [61].

Számos oka lehet annak, ha a beteg nem követi az orvosi utasításokat. A mellékhatások, mint hányás, hányinger, rossz közérzet, hasmenés, puffadás, vagy a bőrt, fóként az arcot érintő tünetek megjelenése általában dózisfüggő és reverzíbilis, tehát a tabletták szedésének befejezésével enyhülnek, majd elmúlnak a panaszok. Jelentős problémát okozhat az is, ha a beteg túl idős vagy feledékeny [62, 63]. Örökletes galaktózintoleranciában, Lapp-laktáz-hiányban vagy glükóz-galaktóz felszívódási zavarban szenvedő betegeknél pedig ritkán egyes tabletták laktóz-monohidrát segédanyag-tartalma jelenthet akadályt. A kezelés sikerességéhez elengedhetetlen a gyógyszer előírásszerú, rendszeres és következetes bevitele, hogy a folyamatos gyógyszer-expozíció megvalósulhasson; az adherencia felmérése az egyes betegeknél ezért fontos [62, 63].

$\mathrm{Az}$ adherencia mérésének számos módszere lehetséges: „önellenőrzés”, tablettaszámlálás, MEMS (microelectronic monitoring system), vényadatbázis-analízis, szérum-, illetve vizeletvizsgálat [62, 63]. A MEMS a gyógyszeres doboz fedelébe ültetett csip, ami segítségével az ellenőrizhető, hogy a dobozt napjában hányszor és mikor nyitották fel: a kihagyott dózisok, illetve a rossz időben történt gyógyszerbevétel gyakorisága így kiszűrhető. Utóbbi nagy hátránya a magas ár, ezért egyelőre inkább csak az adherenciát mérő klinikai vizsgálatokban alkalmazzák [3, 63]. Az Egyesült Államokban a recepteket a gyógyszertárak számítógépes rendszere tárolja, és segítségével viszonylag jól követhető, ha egy beteg túl hamar vagy túl későn váltja ki az újabb „adag” per os rákellenes gyógyszerét. Ez a fajta monitorozás is eléggé költség- és időigényes, és feltételezi, hogy a beteg ugyanabban a gyógyszertárban vagy „patikaláncnál” váltja ki gyógyszerét. Az olyan módszerek, mint a gyógyszerszedési napló vagy naptár nagyban hozzájárulhat a megfelelő adherencia kialakulásához $[19,62,63]$. A naplóba a beteg feljegyzi a bevétel időpontját, a bevett tabletták számát, és a jelentkező mellékhatásokat. Adódhatnak olyan esetek is, amikor a beteg különböző okok miatt nyelésképtelen, vagy a nagyobb méretű gyógyszerekkel nem tud megbirkózni. Erre vonatkozóan is létez- nek megoldások; néhány per os rákgyógyszer összetörhető, feloldható, sőt, ízesítést (málnaszörp) is ajánlanak hozzá, ami elfedi a keserú ízt, de nem befolyásolja a hatóanyag felszívódását [64].

\section{Következtetések}

Az előrejelzések szerint a jövőben egyre több, szájon át alkalmazható daganatellenes szer kerül forgalomba [2]. Sokat ezek közül már klinikai vizsgálatokban tesztelnek. A célzott terápiás szerek egyre bővülő palettája mellett citosztatikumok (például satraplatin) is szerepelnek a vizsgált gyógyszerek között [65]. A második generációs (irreverzíbilis) tirozinkináz-inhibitorok köre még jelentősen bővül, de más hatásmechanizmusú gyógyszerek (például hisztondeacetilázok) tumorellenes hatékonyságát is vizsgálják $[66,67,68]$. A szájon át szedhető daganatellenes gyógyszerek elterjedésével globálisan megfigyelhető az onkológiai ellátás kompetenciaredszerének finom átalakulása. A mellékhatások és interakciók ismerete a minőségi ellátás egyik igen fontos alappillére.

\section{Irodalom}

[1] Goodin, S.: Oral chemotherapeutic agents: Understanding mechanisms of action and drug interactions. Am. J. Health Syst. Pharm., 2007, 64 (Suppl. 5), S15-S24.

[2] Weingart, R., Brown, E., Bach, P. B., et al.: NCCN Task force report: Oral chemotherapy. J. Natl. Compr. Canc. Netw., 2008, 6 (Suppl. 3), S1-S14.

[3] Hartigan, K.: Patient education: The cornerstone of successful oral chemotherapy treatment. Clin. J. Oncol. Nurs., 2003, 7 (6 Suppl.), 21-24.

[4] Colomer, R., Alba, E., González-Martin, A., et al.: Treatment of cancer with oral drugs: a position statement by the Spanish Society of Medical Oncology (SEOM). Ann. Oncol., 2010, 21, 195198.

[5] Bellmunt, J., Eisen, T., Fishman, M., et al.: Experience with sorafenib and adverse event management. Crit. Rev. Oncol. Hematol., 2011, 78, 24-32.

[6] Gore, M. E., Szczylik, C., Porta, C., et al.: Safety and efficacy of sunitinib for metastatic renal-cell carcinoma: an expanded-access trial. Lancet Oncol., 2009, 10, 757-763.

[7] Lynch, T. J., Bell, D. W., Sordella, R., et al.: Activating mutations in the epidermal growth factor receptor underlying responsiveness of non-small-cell lung cancer to gefitinib. N. Engl. J. Med., 2004, 350, 2129-2139.

[8] Geyer, C. E., Forster, J., Lindquist, D., et al.: Lapatinib plus capecitabine for HER2-positive advanced breast cancer. N. Engl. J. Med., 2006, 355, 2733-2743.

[9] Shah, N. P., Kantarjian, H. M., Kim, D. W., et al.: Intermittent target inhibition with dasatinib $100 \mathrm{mg}$ once daily preserves efficacy and improves tolerability in imatinib-resistant and -intolerant chronic-phase chronic myeloid leukemia. J. Clin. Oncol., 2008, 26, 3204-3212.

[10] Jarkowski, A., Sweeney, R. P.: Nilotinib: A new tyrosine kinase inhibitor for the treatment of chronic myelogenous leukemia. Pharmacotherapy, 2008, 28, 1374-1382.

[11] Sternberg, C. N., Davis, I. D., Mardiak, J., et al.: Pazopanib in locally advanced or metastatic renal cell carcinoma: results of a randomized phase III trial. J. Clin. Oncol., 2010, 28, 10611068 . 
[12] Garnock-Jones, K. P., Keating, G. M.: Everolimus: in advanced renal cell carcinoma. Drugs, 2009, 69, 2115-2124.

[13] http://www.ema.europa.eu/docs/en_GB/document_library/ EPAR_-_Public_assessment_report/human/001242/ WC500104417.pdf

[14] Sakamaki, H., Ikeda, S., Yajima, S., et al.: Cost-utility analysis of the oral fluoropyrimidine $S-1$ versus conventional intravenous chemotherapy in advanced or recurrent gastric cancer. Open Health Serv. Policy J., 2009, 2, 26-33.

[15] Desar, I. M., Burger, D. M., Van Hoesel, Q. G., et al.: Pharmacokinetics of sunitinib in an obese patient with a GIST. Ann. Oncol., 2009, 20, 599-600.

[16] Ng, T. R., Chan, A.: Dosing recommendations of targeted cancer therapies in patients with special needs: Evidence and controversies. Crit. Rev. Oncol. Hematol., 2011 Mar 21. [Epub ahead of print]

[17] National Patient Safety Agency (NHS): Rapid Response Report. Risks of incorrect dosing of oral anti-cancer medicines. NPSA/ 2008/RRR01. 2008. http://www.nrls.npsa.nhs.uk/resources/ ?entryid $45=59880$

[18] National Patient Safety Agency: Standards of the safe use of oral anticancer medicines, sussex cancer network oral anti-cancer medicine standards v3.4 1, NHS Sussex Cancer Network, Network Guidance Document Issue Date: July 2008. http://www. sussexcancer.net/professionals/clinicalgroups/crosscutting/ chemo/guidelines/documents/NPSAStandardsforSafeUseofOr alAnticancerMedicinesv3.4.pdf

[19] Moore, S.: Facilitating oral chemotherapy treatment and compliance through patient/family-focused education. Cancer Nurs., 2007, 30, 112-122.

[20] Winkeljobn, D.: Adherence to oral cancer therapies: nursing interventions. Clin. J. Oncol. Nurs., 2010, 14, 461-466.

[21] Held-Warmkessel, J.: Empowering nurses to advocate for improved patient care. ONS News, 2006, 21 (8 Suppl.), 53-54

[22] http://evs.nci.nih.gov/ftpl/CTCAE/CTCAE_4.03_201006-14_QuickReference_5x7.pdf

[23] Viale, P. H., Fung, A., Zitella, L.: Advanced colorectal cancer: current treatment and nursing management with economic considerations. Clin. J. Oncol. Nurs., 2005, 9, 541-552.

[24] Kappers, M. H., van Esch, J. H., Sluiter, W., et al.: Hypertension induced by the tyrosine kinase inhibitor sunitinib is associated with increased circulating endothelin-1 levels. Hypertension, 2010, 56, 675-681.

[25] Chu, T. F., Rupnick, M. A., Kerkela, R., et al.: Cardiotoxicity associated with tyrosine kinase inhibitor sunitinib. Lancet, 2007, 370 (9604), 2011-2019.

[26] Eilers, R. E., Gandhi, M., Patel, J. D., et al.: Dermatologic infections in cancer patients treated with epidermal growth factor receptor inhibitor therapy. J. Natl. Cancer Inst., 2010, 102, 47-53.

[27] Potthoff, K., Hofheinz, R., Hassel, J. C., et al.: Interdisciplinary management of EGFR-inhibitor-induced skin reactions: a German expert opinion. Ann. Oncol., 2011, 22, 524-535.

[28] Tsai, K. Y., Yang, C. H., Kuo, T. T., et al.: Hand-foot syndrome and seborrheic dermatitis-like rash induced by sunitinib in a patient with advanced renal cell carcinoma. J. Clin. Oncol., 2006, 24, 5786-5788.

[29] Lynch, M. P., Rogers, B. B.: Neutropenia. In: Clinical Manual for the Oncology Advanced Practice Nurse. Eds.: Camp-Sorrell, D. Hawkins, R. A. 2nd ed. Oncology Nursing Society, Pittsburgh, PA, 2006, 845-851.

[30] Hui, E. P., Ma, B. B., King, A. D., et al.: Hemorrhagic complications in phase II study of sunitinib in patients of nasopharyngeal carcinoma who has previously received high-dose radiation. Ann. Oncol., 2011, 22, 1280-1287.

[31] NCCN Clinical Practice Guidelines in Oncology. http://www. nccn.org/professionals/physician_gls/f_guidelines.asp

[32] Chang, J., Rand, M., Blumenthal, G. M., et al.; U.S. Food and Drug Administration, Silver Spring, MD: FDA evaluation of hepatotoxicity related tyrosine kinase inhibitors. J. Clin. Oncol., 2011, 29 (Suppl.), abstr. 3106.

[33] Lam, M. S., Ignoffo, R. J.: A guide to clinically relevant drug interactions in oncology. J. Oncol. Pharm. Pract., 2003, 9, 45-85.

[34] Juliano, R. L., Ling, V. A.: A surface glycoprotein modulating drug permeability in Chinese hamster ovary cell mutants. Biochem. Biophys. Acta, 1976, 455, 152-162.

[35] Riordan, J. R., Deuchars, K., Kartner, N., et al.: Amplification of P-glycoprotein genes in multidrug-resistant mammalian cell lines. Nature, 1985, 316, 817-819.

[36] Kartner, N., Evernden-Porelle, D., Bradley, G., et al.: Detection of P-glycoprotein in multidrug-resistant cell lines by monoclonal antibodies. Nature, 1985, 316, 820-823.

[37] Roninson, I. B., Chin, J. E., Choi, K., et al.: Isolation of human mdr DNA sequences amplified in multidrug-resistant $\mathrm{KB}$ carcinoma cells. Proc. Natl. Acad. Sci. USA, 1986, 83, 4538-4542.

[38] Higgins, C. F.: ABC transporters: from microorganisms to man. Annu. Rev. Cell Biol., 1992, 8, 67-113.

[39] Sparreboom, A., van Asperen J., Mayer, U., et al.: Limited oral bioavailability and active epithelial excretion of paclitaxel caused by P-glycoprotein in the intestine. Proc. Natl. Acad. Sci. USA, 1997, 94, 2031-2035.

[40] Bardelmeijer, H. A., van Tellingen, O., Schellens, J. H., et al.: The oral route for the administration of cytotoxic drugs: strategies to increase the efficiency and consistency of drug delivery. Invest. New Drugs, 2000, 18, 231-241.

[41] Van Asperen, J., van Tellingen, O., Sparreboom, A., et al.: Enhanced oral bioavailability of paclitaxel in mice treated with the P-glycoprotein blocker SDZ PSC 833. Br. J. Cancer, 1997, 76, 1181-1183.

[42] Slaviero, K. A., Clarke, S. J., Rivory, L. P.: Inflammatory response: an unrecognised source of variability in the pharmacokinetics and pharmacodynamics of cancer chemotherapy. Lancet Oncol., 2003, 4, 224-232.

[43] Baker, S. D., van Shaik, R. H., Rivory, L. P., et. al.: Factors affecting cytochrome P-450 $3 \mathrm{~A}$ activity in cancer patients. Clin. Cancer Res., 2004, 10, 8341-8350.

[44] Undevia, S. D., Gomez-Abuin, G., Ratain, M. J.: Pharmacokinetic variability of anticancer agents. Nat. Rev. Cancer, 2005, 5, 447-458.

[45] Wong, C. M., Ko, ., Chan, A.: Clinically significant drug-drug interactions between oral anticancer agents and nonanticancer agents: profiling and comparison of two drug compendia. Ann. Pharmacother., 2008, 42, 1737-1748.

[46] Hlubocky, F. J., Ratain, M. J., Wen, M., et al.: Complementary and alternative medicine among advanced cancer patients enrolled on phase I trials: a study of prognosis, quality of life, and preferences for decision making. J. Clin. Oncol., 2007, 25, 548554.

[47] McCune, J. S., Hatfield, A. J., Blackburn, A. A., et al.: Potential of chemotherapy-herb interactions in adult cancer patients. Support. Care Cancer, 2004, 12, 454-462.

[48] Lehmann, J., McKee, D. D., Watson, M. A., et al.: The human orphan nuclear receptor PXR is activated by compounds that regulate CYP3A4 gene expression and cause drug interactions. J. Clin. Investig., 1998, 102, 1016-1023.

[49] Moore, L. B., Goodwin, B., Jones, S. A., et al.: St. John's wort induces hepatic drug metabolism through activation of the pregnane X receptor. Proc. Natl. Acad. Sci. USA, 2000, 97, 75007502 .

[50] Blower, P., de Wit, R., Goodin, S., et al.: Drug-drug interactions in oncology: why are they important and can they be minimized? Crit. Rev. Oncol. Hematol., 2005, 55, 117-142.

[51] Meijerman, I., Beijnen, J. H., Schelens, J. H. M.: Herb-drug interactions in oncology: focus on mechanisms of induction. Oncologist, 2006, 11, 742-752. 
[52] Riechelmann, R. P., Moreira, F., Smaletz, O., et al.: Potential for drug interactions in hospitalized cancer patients. Cancer Chemother. Pharmacol., 2005, 56, 286-290.

[53] Scripture, C., Figg, W. D.: Drug interactions in cancer therapy. Nat. Rev. Cancer, 2006, 6, 546-558.

[54] Beijnen, J. H., Schellens, J. H.: Drug interactions in oncology. Lancet Oncol., 2004, 5, 489-496.

[55] Van Erp, N., Gelderblom, H., van Glabbeke, M., et al.: Effect of cigarette smoking on imatinib in patients in the soft tissue and bone sarcoma group of the EORTC. Clin. Cancer Res., 2008, $14,8308-8313$

[56] Bagshawe, K. D., Burke, P. J., Knox, R. J., et al.: Targeting enzymes to cancers - new developments. Expert Opin. Investig. Drugs, 1999, 8, 161-172.

[57] Verbeeck, R. K.: Pharmacokinetics and dosage adjustment in patients with hepatic dysfunction. Eur. J. Clin. Pharmacol., 2008, 64, 1147-1161.

[58] Wong, S. F.: New dosing schedules of dasatinib for CML and adverse event management. J. Hematol. Oncol., 2009, 2, 10.

[59] Koch, K. M., Reddy, N. J., Cohen, R. B., et al.: Effects of food on the relative bioavailability of lapatinib in cancer patients. J. Clin. Oncol., 2009, 27, 1191-1196.

[60] Haynes, R. B., Taylor, D. W., Sackett, D. L.: Compliance in health care. Johns Hopkins University Press, Baltimore, 1979.

[61] Horne, R., Weinman, J., Barber, N., et al.: Concordance, adherence and compliance in medicine taking. Report for the National Co-ordinating Centre for HS Service Delivery and Organisation R \& D (NCCSDO). December 2005. http://www. medslearning.leeds.ac.uk/pages/documents/useful_docs/76final-report $\% 5 \mathrm{~B} 1 \% 5 \mathrm{D}$.pdf
[62] Viele, C.: Managing oral chemotherapy: The healthcare practitioner's role. Am. J. Health Syst. Pharm., 2007, 64 (9, Suppl. 5), S25-S32.

[63] Ruddy, K., Mayer, E., Partridge, A.: Patient adherence and persistence with oral anticancer treatment. CA Cancer J. Clin., 2009, 59, 56-66.

[64] The NEWT Guidelines for administration of medication to patients with enteral feeding tubes or swallowing difficulties. Ed.: Smyth, J. North East Wales NHS Trust, 2006.

[65] Ricart, A. D., Sarantopoulos, J., Calvo, E., et al.: Satraplatin, an oral platinum, administered on a five-day schedule: a pharmacokinetic and food effect study. Clin. Cancer Res., 2009, 15, 3866-3871.

[66] Sequist, L. V.: Second-generation epidermal growth factor receptor tyrosine kinase inhibitors in non-small cell lung cancer. Oncologist, 2007, 12, 325-330.

[67] Wilmes, L. G., Pallavicini, M. G., Fleming, L. M., et al.: AG013736, a novel inhibitor of VEGF receptor tyrosine kinases, inhibits breast cancer growth and decreases vascular permeability as detected by dynamic contrast-enhanced magnetic resonance imaging. Magn. Reson. Imaging, 2007, 25, 319-327.

[68] Jänne, P. A., Boss, D. S., Camidge, D. R., et al.: Phase I doseescalation study of the pan-HER inhibitor, PF299804, in patients with advanced malignant solid tumors. Clin. Cancer Res., 2011, 17, 1131-1139.

(Bartal Alexandra dr., Budapest, Ráth György u. 7-9., 1122 e-mail: alexandra.bartal@gmail.com)
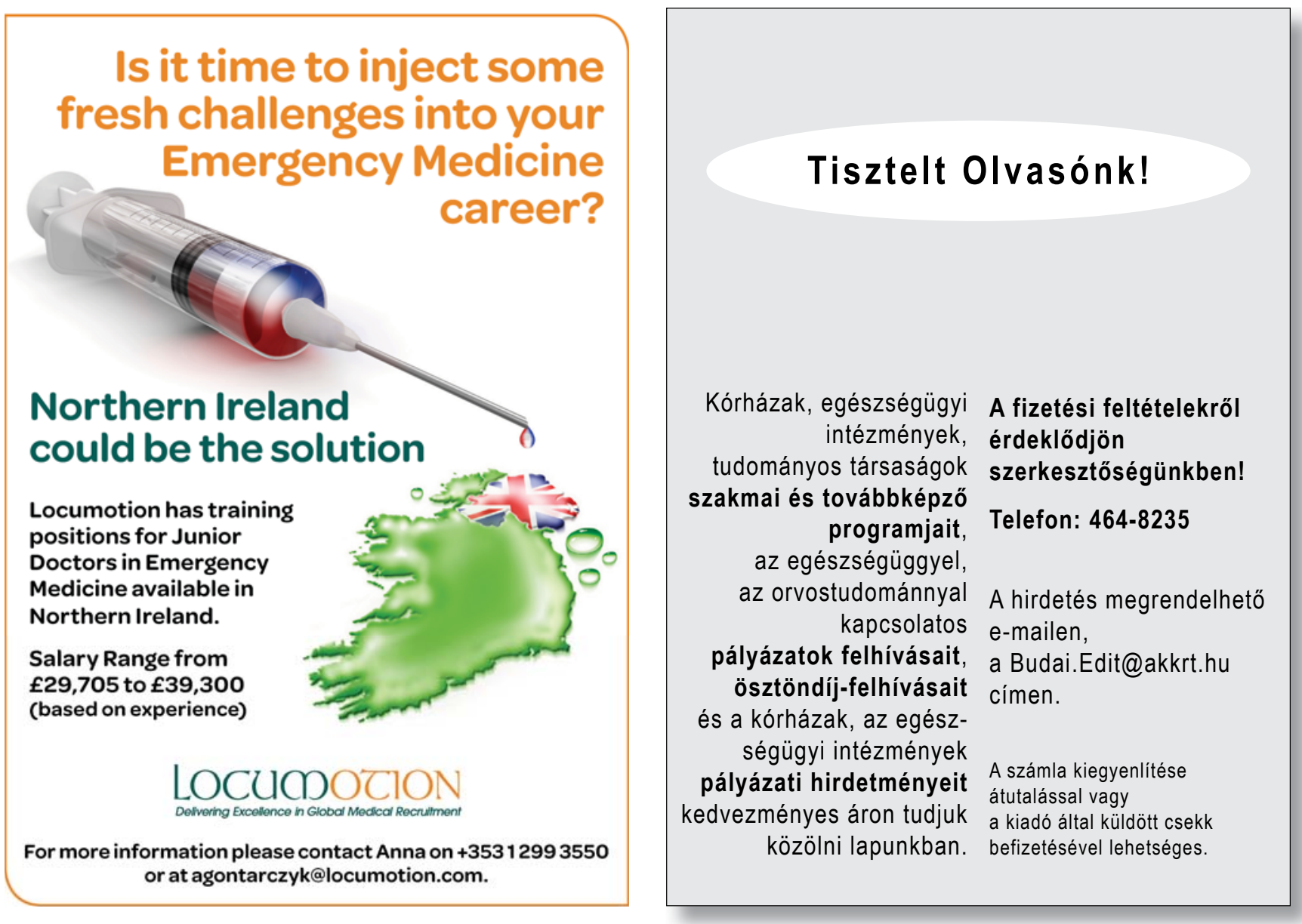